\title{
Effect of geographical discontinuity on genetic variation in Quercus ilex L. (holm oak). Evidence from enzyme polymorphism
}

\author{
H. MICHAUD, L. TOUMI, R. LUMARET*, T. X. LI, F. ROMANE† \& F. DI GIUSTO \\ Département de Biologie des Populations and †Département pour l'étude de la dynamique des systèmes écologiques \\ et des perturbations, Centre d'Ecologie Fonctionnelle et Evolutive (CEFE) Louis Emberger, CNRS, BP 5051, \\ 34033 Montpellier Cedex, France
}

\begin{abstract}
Allozymes at a maximum of eight loci were used to analyse the spatial patterns of genetic variation in 1942 holm oak trees (Quercus ilex L.) from 57 provenances distributed in the six main disjunct areas of the species distribution area. Polymorphism and genetic diversity were high except in the six marginal populations growing in various locations under unfavourable climatic conditions. Ten per cent of the total genetic diversity $\left(H_{\mathrm{t}}=0.262\right)$ was accounted for by among-population variation. In this long-lived species, the effect of geographical discontinuities on gene flow restriction was shown by the occurrence of: (i) numerous rare alleles limited to a single disjunct region; and (ii) allele frequency variation among the disjunct regions for four alleles. This result was obtained by comparing spatial autocorrelograms from the 57 populations of the entire distribution area and from the 31 populations of the Mediterranean continental region which constitutes the largest continuous area in that distribution. Life history traits (e.g. long life span and high outcrossing rate) and past changes in climate and geographical continuity are assumed to be the main factors responsible for the present genetic variation patterns observed in the species.
\end{abstract}

Keywords: allozyme differentiation, long-term isolation, Quercus ilex.

\section{Introduction}

Many genetic studies using enzyme polymorphism in forest tree species have shown the occurrence of very high genetic diversity, especially within populations, whereas low differentiation has been observed among populations (Hamrick et al., 1979). Spatial genetic homogeneity is usually attributed to the occurrence of high gene flow among trees in long-lived, windpollinated species which possess, therefore, very high dispersal ability (Levin \& Kerster, 1974; Loveless \& Hamrick, 1984; Govindaraju, 1988). However, population differentiation may also occur by mutation, differential selection or genetic drift, provided that seed and/or, more particularly, pollen dispersal are limited (Slatkin, 1987). In coniferous species, gene flow reduction has been shown to occur between populations isolated on islands and those growing on the continent (Fineschi, 1984), between populations distributed on two opposite sides of the same mountain (Chung, 1991) or in populations isolated in marginal areas (Furnier \& Adams, 1986; Betancourt et al.,

*Correspondence.
1991; Zabinski, 1992). In broad-leaved tree species which have been shown to possess the same level of genetic diversity and geographical homogeneity as coniferous species (Hamrick et al., 1992; MüllerStarck et al., 1992), very little is known about the effects of long-term gene flow reduction from geographical discontinuity on genetic differentiation (e.g. Haase, 1992). The aim of the present study is to assess the effect of long-term spatial discontinuity on the genetic structure of the holm oak (Quercus ilex L.) by using allozyme markers.

The holm oak is a broad-leaved, evergreen, longlived tree species able to resprout from roots and stumps. It is mostly wind-pollinated and outcrossing even though each tree bears both male and female inflorescences (Lumaret et al., 1991). Acorn dispersal by small mammals and large birds is assumed to be very limited compared with pollen dispersal (Ducousso et al., 1993). The holm oak is mostly distributed in the western part of the Mediterranean basin, in three distinct areas: (i) North Africa from Tunisia to Morocco; (ii) on several large islands, e.g. Crete, Sicily and Corsica; and (iii) in southern (continental) Europe, along a continuum from Turkey to Portugal. 
In addition, the species is regularly distributed along the Atlantic coast of France from the Bordeaux basin to the Loire river. Palaeoecological data indicate that the holm oak has occurred in the south of Europe and in North Africa since the end of the Tertiary period (Pons \& Vernet, 1971; Palamarev, 1989). According to Pons \& Vernet (1971), holm oak populations from the Atlantic area have a Quaternary history distinct from that of the Mediterranean populations. Since $4500 \mathrm{BP}$, at least in the wettest part of its Mediterranean distribution, the holm oak had been favoured by human activities such as pastoralism or clearing by burning (Pons \& Thinon, 1987; Reille \& Pons, 1992). However, in most of the distribution area, holm oak forests can be regarded as rare cases of woodlands that have undergone very low or no silvicultural management. By contrast, in central Spain, the holm oak is considered as a fruit tree and has been selected for sweet acorn production to feed pigs (Ruperez, 1957).

Two main morphological types of holm oak have been described. The 'rotundifolia' type is a small round-leaved morph occurring in inland parts of Spain and North Africa where it grows under Mediterranean climates ranging from semiarid (with markedly continental conditions) to perhumid. The 'ilex' type is a large, elongated leaf morph distributed from Turkey to the French Riviera, and along the Atlantic coast of France. This morph is restricted to humid or subhumid sites mainly in mild coastal areas (Barbero et al., 1992). The two morphotypes have been considered either as two distinct species (Schwartz, 1964; Saenz de Rivas, 1972; Afzal-Rafii, 1988; Afzal-Rafii et al., 1991a,b, 1992), two subspecies (Saenz de Rivas, 1967, 1970) or simply two varieties (Maire, 1961). In addition, trees showing morphological characters intermediate between those of the two morphs described above occur in the Mediterranean region of France and in the eastern and northern coastal areas of Spain.

Owing to the pollination system of the holm oak, its long fecundity period and its outcrossing reproductive system, substantial gene flow is expected to occur among populations. Conversely, discontinuities in its geographical distribution because of early colonization around the Mediterranean Basin (before the Gibraltar Detroit was formed, i.e. approximately five million years ago according to Bocquet et al., 1978), may be responsible for genetic differentiation among the isolated areas. In the present study, we address three major questions. (i) Is the level of genetic diversity, within and among populations, similar over the whole distribution area? (ii) Do marginal populations which mostly grow in small discontinuous areas show reduced genetic variation, as has been observed in other species (Mayr, 1975; Hamrick et al. 1989; van
Treuren et al., 1991)? (iii) What is the effect of large geographical discontinuities, and of ancient isolation, on the genetic structure of the holm oak?

\section{Materials and methods}

\section{Origin of plant material and sampling procedure}

Fifty-seven populations were sampled over the whole distribution area of the holm oak (Fig. 1). Populations were natural except those from nos 19-23 which were introduced into Brittany about one century ago (Dupont, 1990). Eleven populations were collected in marginal areas where the holm oak showed a patchy distribution. Six of those marginal populations, namely nos 9, 17, 37, 39, 44 and 47 (Table 1), were located in areas where the holm oak distribution was limited by climatic constraint such as frost or soil moisture (Quezel, 1976). The five other populations, nos 28, 29, 30,31 and 54, were found growing under normal climatic conditions for the species, in areas where the patchy distribution was a result mainly of human activity (cultivation). Collecting sites were distributed over a great range of parent rocks and elevations (Table 1). Climatic data were obtained from various sources (Walter \& Lieth, 1960-1967; Garnier, 1964, 1966; Lombardo, 1973; Font Tullot, 1983; Le Houérou, 1989). The populations were classified as 'ilex', 'rotundifolia' or 'intermediate type' according to Schwartz's morphological criteria (1964). A small, leafed branch was collected from an average of 34 individual trees per population (range 15-59 trees; Table 1).

\section{Allozyme analysis}

Proteins were extracted from leaves (from 1 to 12 months old) in a Tris- $\mathrm{HCl}$ buffer ( $\mathrm{pH} \mathrm{7.6)} \mathrm{and} \mathrm{were}$ stored at $-80^{\circ} \mathrm{C}$ until analysis, as described in Yacine \& Lumaret (1989). Horizontal starch gel electrophoresis was performed for six enzyme systems: PGI, EC 5.3.1.9 (coding for phosphoglucose isomerase with two loci, PGI-1 and -2), ADH, EC 1.1.1.1 (alcohol dehydrogenase, locus $A D H-1$ ), IDH, EC 1.1.1.42 (isocitrate dehydrogenase, locus $I D H-1)$, PX, EC 1.11.1.7 (peroxidase, locus $P X-1$ ), LAP, EC 3.4.11.1 (leucine aminopeptidase, locus $L A P-1$ ) and AcPH, EC 3.1.3.2 (acid phosphatase, locus $A C P H-1$ ). The composition of gels and electrode buffers and the methods used to stain allozyme bands were described in Yacine \& Lumaret (1989) for the PGI, ADH and IDH systems, in Michaud et al. (1992) for peroxidases, in Ouazzani et al. (1993) for leucine aminopeptidases and in Lumaret (1981) for acid phosphatases, respectively. 


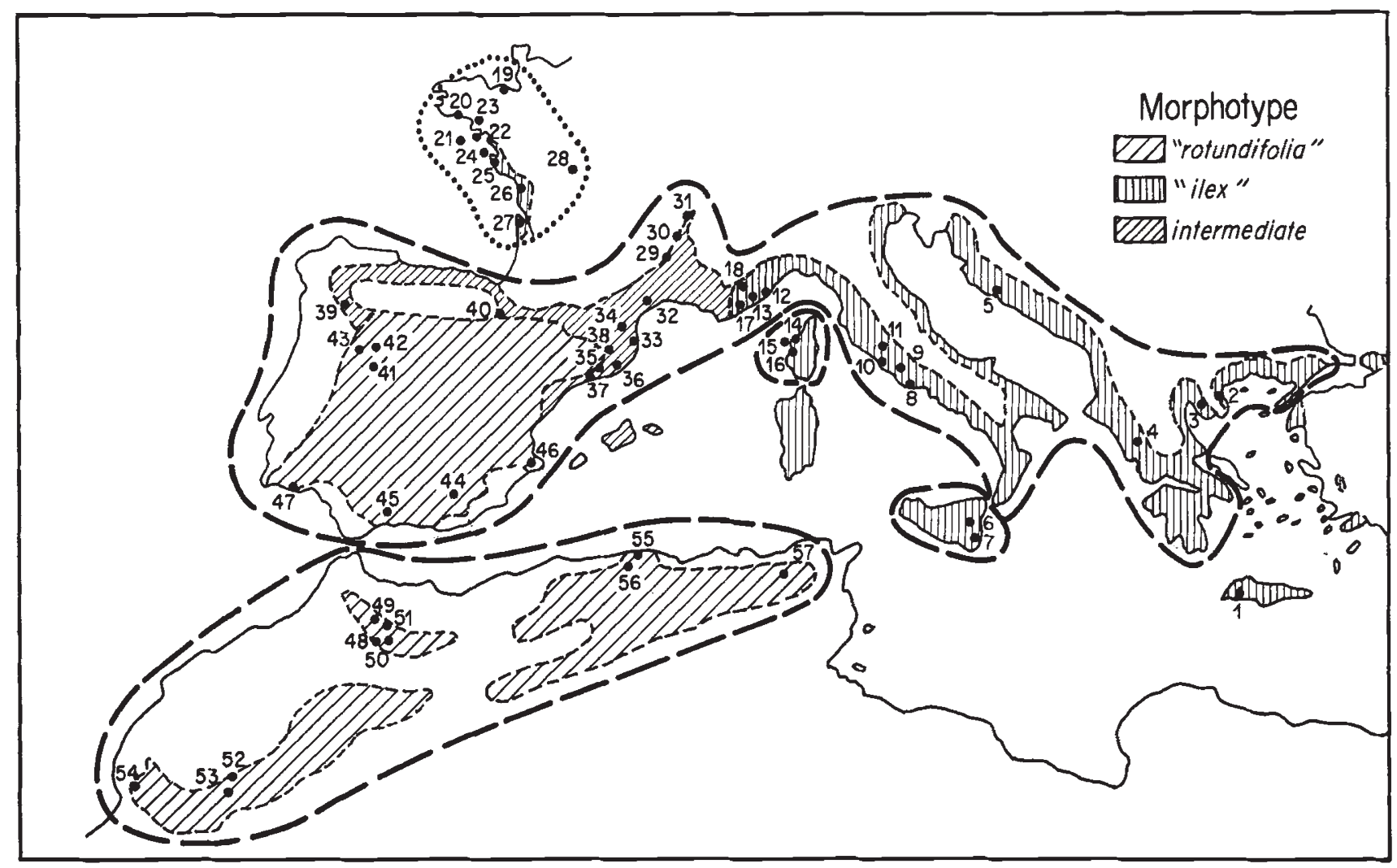

Fig. 1 Natural geographical distribution of holm oak (three morphotypes). Distribution areas corresponding to ancient (five million years) and recent $(700000$ years) disjunctions are surrounded with dashes and dots, respectively. The 57 populations studied are also located and numbered on the map.

For tetrazolium oxidases, EC 1.15.1.1 (locus TO-1), vertical zonal polyacrylamide gels were prepared following Gasques \& Compoint (1976) and were stained according to Selander et al. (1971). At each locus, the index value 1.00 was given to the most frequent allele whereas the other ones were numbered according to their relative mobility.

Inheritance of PGI, ADH and IDH isozymes was studied by Yacine \& Lumaret (1989). To examine the genetic control of PX, LAP and AcPH isozymes, phenotype variation was analysed in the progeny of controlled crosses. At each locus, observed genotype frequencies in the progenies were compared with the frequencies expected under Mendelian segregation using a $\chi^{2}$-test. For TO, the study of genetic determination was limited by the lack of suitable parental genotypes.

The 57 populations were scored for polymorphism at six loci: PGI-1, PGI-2, ADH-1,IDH-1, $P X-1$ and TO-1. Ten populations from the Atlantic area (nos 19-28 in Fig. 1) and 12 populations (nos 4, 6, 10, 11, 13, 29, 30, 31, 32, 37, 44 and 46 in Fig. 1) from the
European Mediterranean area were scored for two additional loci, $L A P-1$ and $A c P H-1$.

\section{Statistical analysis}

Genotypic and allelic frequencies were assessed at each locus from a survey of gel phenograms. $G$-tests for heterogeneity of allele frequencies among populations were carried out according to Sokal \& Rohlf (1981). The data were also used to calculate the total number of alleles per locus, percentage of polymorphic loci, real and effective number of alleles per population ( $A$ and $A_{\mathrm{e}}$, respectively), observed heterozygosity $\left(H_{\mathrm{o}}\right)$, total genetic diversity $\left(H_{\mathrm{t}}\right)$, within-population genetic diversity $\left(H_{\mathrm{s}}\right)$, among-populations genetic diversity $\left(D_{\text {st }}\right)$ and the proportion of diversity resulting from gene differentiation among populations $\left(G_{\text {st }}\right)$ (Nei, 1973, 1987). Genotypic data were analysed using $F$ - statistics (Wright, 1965). Departure of $F_{\text {is }}$ values from zero was tested for each population at each locus by the method proposed by $\mathrm{Li} \&$ Horvitz (1953). 


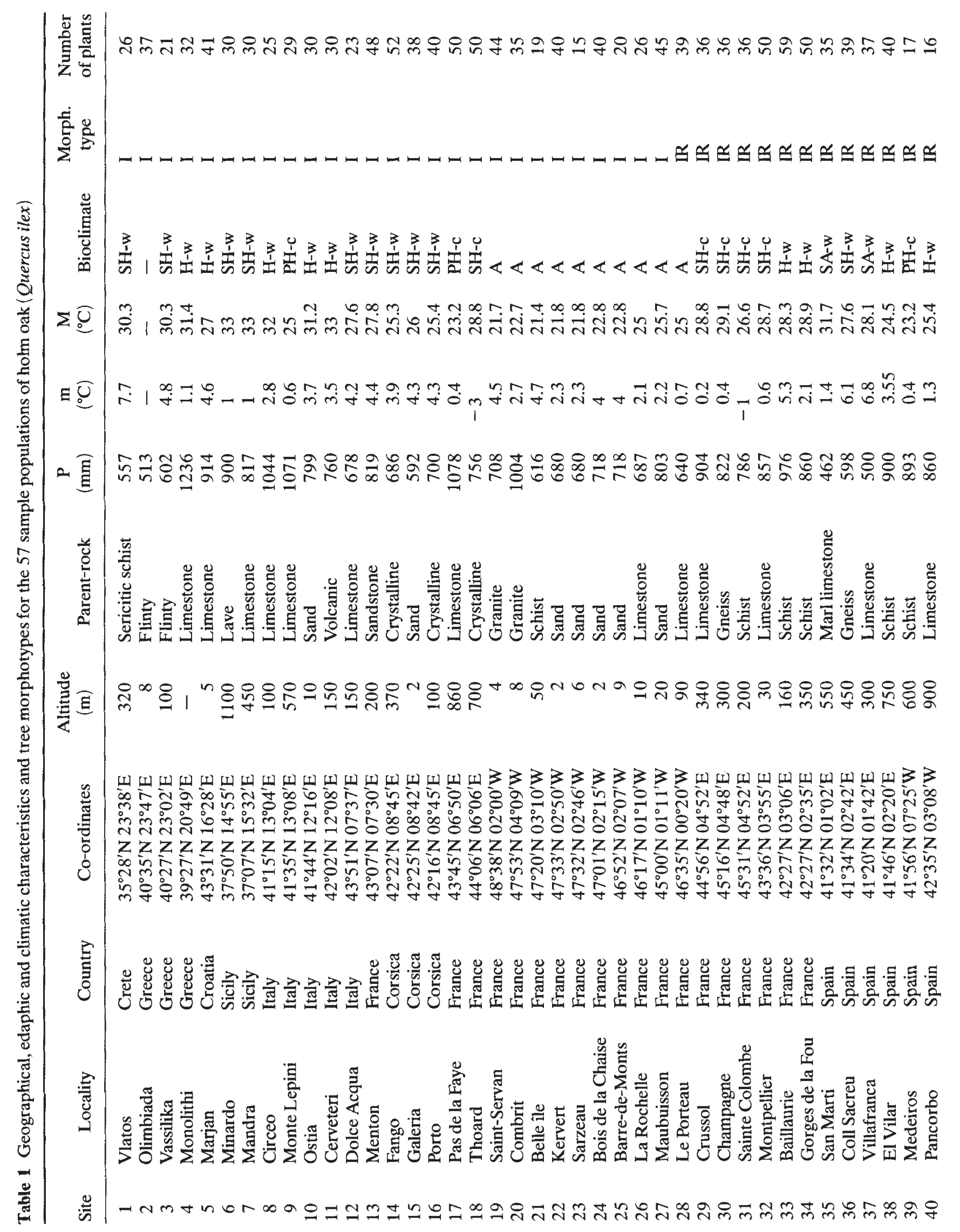

(C) The Genetical Society of Great Britain, Heredity, 74, 590-606. 


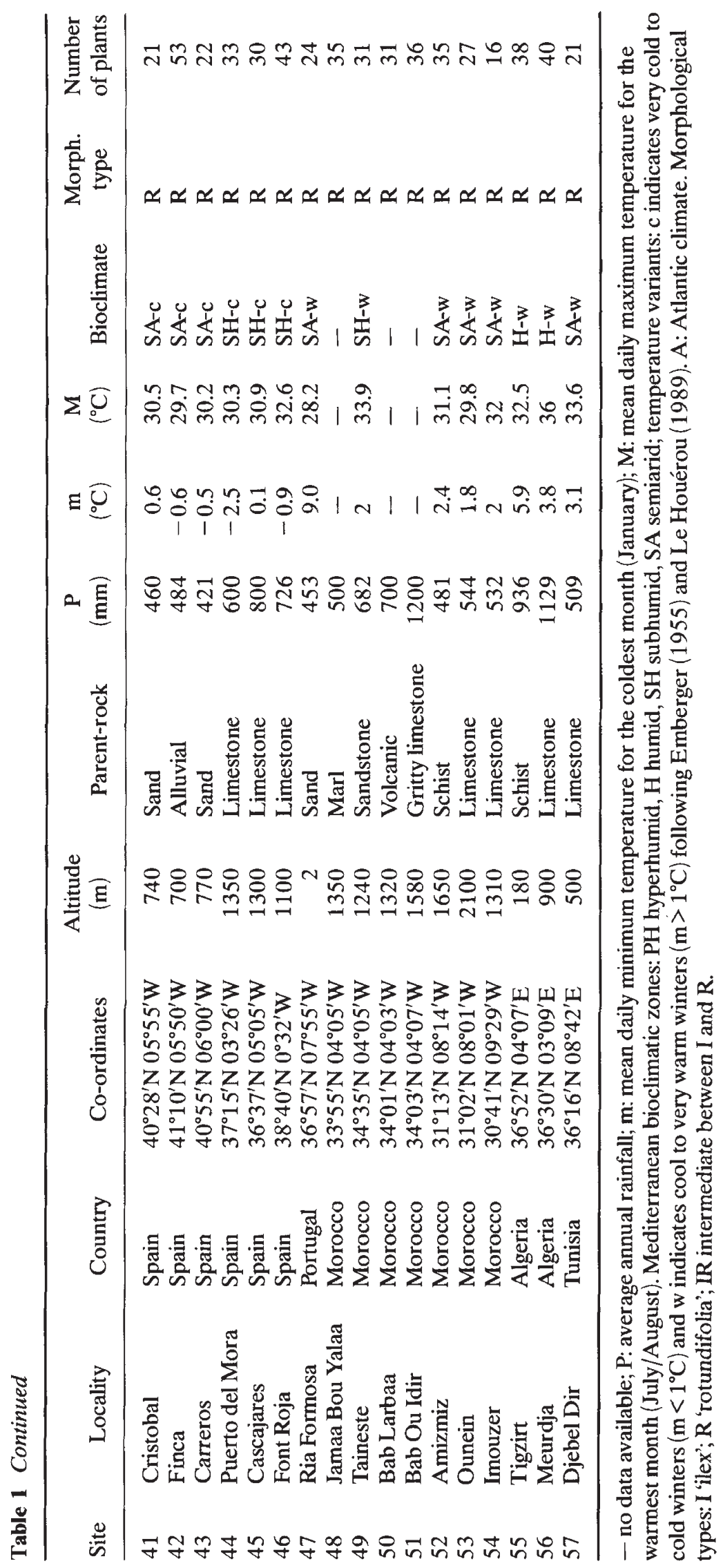

(c) The Genetical Society of Great Britain, Heredity, 74, 590-606. 
The number of migrants exchanged per generation $(\mathrm{Nm})$ was also estimated from the $F_{\text {st }}$ value (Wright, 1951). All the analyses above were performed using the BIosys-1 computer program (Swofford \& Selander, 1989).

The genetic distances of Nei (1978), Gregorius (1984) and a $\chi^{2}$ distance were calculated between pairs of populations from their allelic distributions. The $\chi^{2}$ distance, weighted by the average frequency of each allele in all the populations, has the property of maximizing the effects of rare alleles (Yacine \& Lumaret, 1989). The respective positions of the populations estimated by the distances between them were plotted in a multidimensional space and then projected onto a plane by nonmetric multidimensional scaling (or proximity analysis) (Escoufier, 1975). The same distances were also used as the basis for a hierarchical cluster analysis (UPGMA) with the 'average distance' as the clustering criterion (Roux, 1985). Clusters at different levels of agglomeration (total ranging from 0 to 100 per cent) were mapped onto the diagram obtained from the multidimensional scaling so that the agreement between the results from the two methods could easily be compared. These analyses were performed using the BIOMECo computer package (Lebreton et al., 1987). Dendrograms obtained from each of the 3 genetic distance estimations were also computed with the NTSYs computer package (Rohlf, 1987) and tested with cophenetic matrix correlation to establish the most significant one.

To assess the effect of geographical discontinuities on genetic variation, the populations were separated into five geographical groups (Mediterranean continental Europe, North Africa, Corsica, Sicily and the French Atlantic coast) which correspond to five disjunct distribution areas (Fig.1). In North Africa, palaeobotanical studies have shown that the distinct holm oak distribution areas observed presently were connected in the very recent past (Reille, 1976; Lamb et al., 1989). Therefore, these areas were considered as a whole in the present study. The single population from Crete was not considered in this study. Gene diversity between populations $\left(G_{\text {st }}\right)$ was further subdivided into variation among groups $\left(G_{\mathrm{gt}}\right)$ and among populations within groups $\left(G_{\mathrm{sg}}\right)$. Moreover, spatial autocorrelation (SA) analysis (Sokal \& Oden, 1978a,b) was carried out as a way of looking for correlated (similar or dissimilar) values of gene frequencies in populations that are a given geographical distance apart from each other. SA was carried out separately on the 57 populations located in the whole distribution area (set 1) and on the 31 populations from the Mediterranean continental Europe group (set 2) which constitutes the largest continuous distribution area for the species. Latitudes and longitudes expressed in degrees were transformed into 'extended Lambert 2 co-ordinates' which enabled the computation of the distance in kilometres between the two members of any pair of populations (Petit et al., 1993). For each set of data, a matrix of geographical distances between all pairs of populations was calculated. The distances were then grouped in discrete classes, with class intervals of $400 \mathrm{~km}$. A Moran's (1950) autocorrelation index (I) which varies between -1 and +1 and a Standard Normal Deviate (SDN) were computed for each allele in each distance class. A significant spatial pattern is indicated at the 5 per cent probability level when SND $>1.96$. A correlogram in which Moran's $I$ values were plotted vs. distance classes was then built for each allele studied and correlogram significance was tested by the Bonferroni procedure (Oden, 1984).

\section{Results}

\section{Survey of gel-banding patterns and enzyme genetic control}

Peroxidases $(P X)$. Of the four zones of activity observed on the gels, only the second fastest zone had interpretable banding patterns. Examples of observed phenotypes are given in Fig. 2a. Three classes of parental phenotypes were available; one was inferred to be homozygotes (single-banded phenotypes) and the others were inferred to be distinct heterozygotes (twobanded phenotypes). Crosses between an inferred homozygote and heterozygotes (crosses 2 and 3 in Table 2) produced two classes of progeny with singleor double-banded phenotypes in approximately equal proportions. Crosses between inferred identical homozygotes produced only the parental one-banded phenotype. These results suggest that the variability found in this zone of activity is controlled by a single polymorphic locus, $P X-1$. This locus codes for a functionally monomeric enzyme with seven codominant alleles, namely $P X-1^{0.85}, P X-1^{0.93}, P X-1^{0.96}, P X$ $1^{1.00}, P X-1^{1.03}, P X-1^{1.06}$ and $P X-1^{1.08}$.

Leucine aminopeptidase ( $L A P$ ). Two zones of activity were observed on the gels. Only the faster was regularly interpretable (Fig. 2b). The cross between an inferred homozygote (one-banded phenotype) and a heterozygote (double-banded phenotype) produced two classes of progeny with either single- or doublebanded phenotypes in approximately equal proportions (cross 2 in Table 2). These results support the interpretation that LAP is coded by a single locus $L A P-1$, with three codominant alleles $\left(L A P-1^{0.94}\right.$, $L A P-1^{0.96}$ and $\left.L A P-1^{1.00}\right)$ which specify monomeric enzymes. 

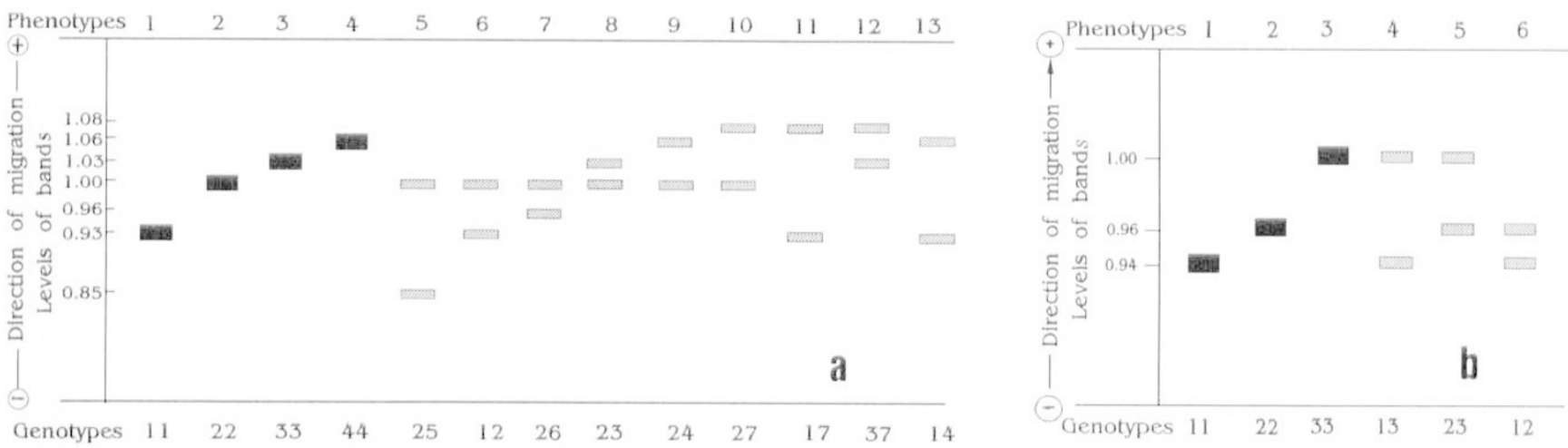

Fig. 2 Schematic pattern of (a) PX and (b) LAP zymograms. Band mobilities at $P X-1,1=0.93,2=1.00,3=1.03,4=1.06$, $5=0.85,6=0.96$ and $7=1.08$; at $L A P-1,1=0.94,2=0.96$ and $3=1.00$.

Table 2 Inheritance patterns at three loci in Quercus ilex L.

\begin{tabular}{|c|c|c|c|c|c|c|}
\hline Locus & $\begin{array}{c}\text { Cross } \\
\text { no. }\end{array}$ & $\begin{array}{l}\text { Presumed parental } \\
\text { genotypes }\end{array}$ & $\begin{array}{l}\text { Offspring } \\
\text { Observed }\end{array}$ & $\begin{array}{l}\text { notypes } \dagger \\
\text { xpected) }\end{array}$ & Total & $\chi^{2}$ \\
\hline \multirow{6}{*}{$P X-1$} & & & $1.00 / 1.00$ & & & \\
\hline & 1 & $1.00 / 1.00 \times 1.00 / 1.00$ & 6 & & 6 & \\
\hline & & & $1.00 / 1.00$ & $1.00 / 1.06$ & & \\
\hline & 2 & $1.00 / 1.00 \times 1.00 / 1.06$ & $13(12.5)$ & $12(12.5)$ & 25 & NS \\
\hline & & & $1.00 / 1.06$ & $1.00 / 0.93$ & & \\
\hline & 3 & $1.00 / 1.00 \times 1.06 / 0.93$ & $7(7.5)$ & $8(7.5)$ & 15 & NS \\
\hline \multirow{4}{*}{$L A P-1$} & & & $1.00 / 1.00$ & & & \\
\hline & 1 & $1.00 / 1.00 \times 1.00 / 1.00$ & 14 & & 14 & \\
\hline & & & $1.00 / 1.00$ & $1.00 / 0.94$ & & \\
\hline & 2 & $1.00 / 1.00 \times 1.00 / 0.94$ & $12(9.5)$ & $7(9.5)$ & 19 & NS \\
\hline \multirow[t]{4}{*}{$A C P H-1$} & & & $1.00 / 1.00$ & & & \\
\hline & 1 & $1.00 / 1.00 \times 1.00 / 1.00$ & 11 & & 11 & \\
\hline & & & $1.00 / 1.00$ & $1.00 / 0.83$ & & \\
\hline & 2 & $1.00 / 1.00 \times 1.00 / 0.83$ & $7(5.5)$ & $4(5.5)$ & 11 & NS \\
\hline
\end{tabular}

†Genotypes are indicated with bold characters. Expected genotypic frequencies are in parentheses. NS = no significant difference between observed and expected frequencies.
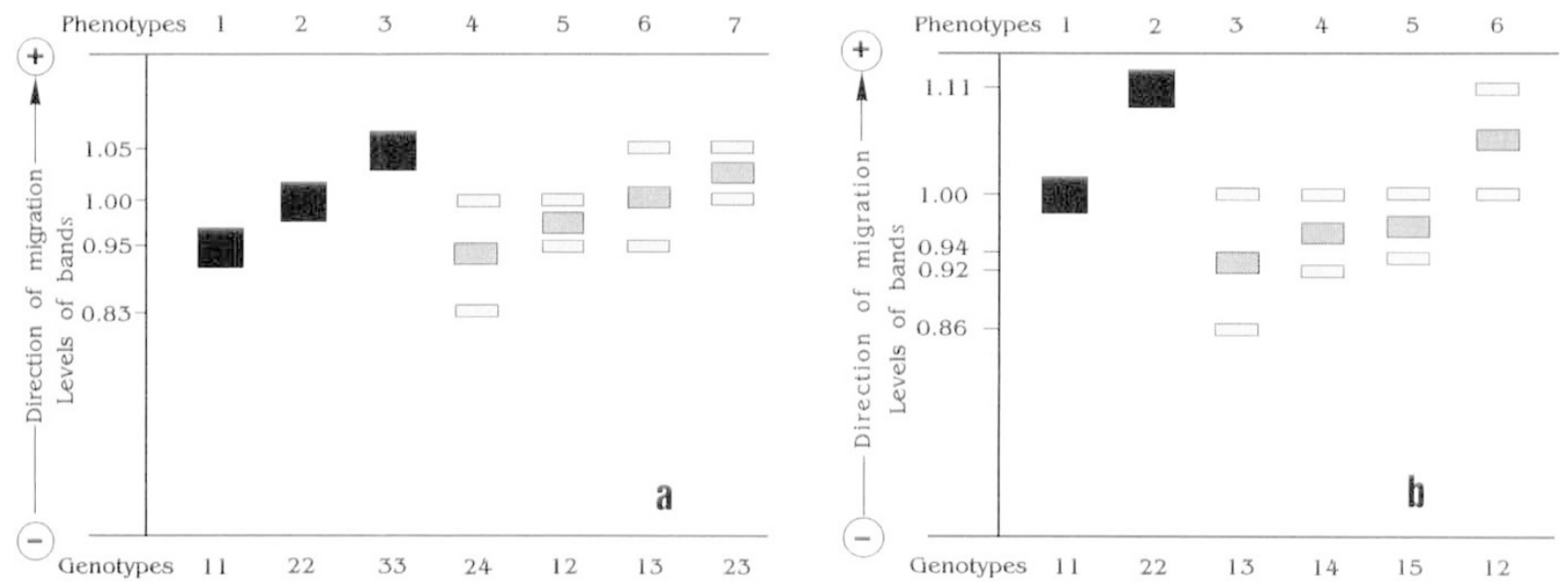

Fig. 3 Schematic pattern of (a) AcPH and (b) TO zymograms. Band mobilities at $A c P H-1,1=0.95,2=1.00,3=1.05$ and $4=0.83$; at $T O-1,1=1.00,2=1.11,3=0.86,4=0.92$ and $5=0.94$. 
Acid phosphatase $(A c P H)$. Four zones of activity were observed on the gels, the fastest being the only one interpretable (Fig. 3a). The inferred homozygotes showed a single band of activity whereas the inferred heterozygotes possessed three bands with intense activity for the intermediate band. Genotypic segregation in cross 2 (Table 2) did not deviate significantly from that expected assuming a single-locus inheritance. These results support the interpretation that in that zone of activity AcPH is coded by a single locus $(A c P H-1)$ with four codominant alleles $\left(A C P H-1^{0.83}\right.$, $A c P H-1^{0.95}, A c P H-1^{1.00}$ and $\left.A c P H-1^{1.05}\right)$ which specify dimeric enzymes.

Tetrazolium oxidase (TO). Three zones of activity were observed on the gels. Only the fastest zone was interpretable. Examples of observed single- and threebanded phenotypes are shown in Fig. 3b. A single class of parental genotype was observed and was inferred to be homozygote. Crosses between two of these inferred homozygotes produced a single class of progeny with the parental pattern. According to the banding patterns and to general agreement regarding enzyme substructure in higher plants (Gottlieb, 1977; Kephart, 1990), the tetrazolium oxidase system was considered to resolve one putative locus, $T O-1$, with five codominant alleles which code for dimeric enzymes. The alleles were $T O-1^{0.86}, T O-1^{0.92}, T O-1^{0.94}, T O-1^{1.00}$ and TO$1^{1.11}$.

Other enzyme systems. In addition, 11, four and six alleles were observed at the PGI-1, IDH-1 and $A D H-1$ loci, respectively, among the 57 populations. These alleles are: $P G I-1^{0.66}, P G I-1^{0.74}, P G I-1^{0.80}$, PGI-1 ${ }^{0.90}$, PGI-1 $1^{0.92}$, PGI-1 ${ }^{0.95}$, PGI-1 $1^{1.00}$, PGI-1 ${ }^{1.09}$, PGI-1 $1^{1.20}$, $P G I-1^{1.33}$ and PGI-1 $1^{1.40} ; I D H-1^{0.76}, I D H-1^{1.00}, I D H-$ $1^{1.10}$ and $I D H-1^{1.30} ; A D H-1^{0.55}, A D H-1^{0.76}, A D H-1^{1.00}$, $A D H-1^{1.16}, A D H-1^{1.25}$ and $A D H-1^{1.36}$.

\section{Genetic variation in Quercus ilex}

Among the eight loci analysed (with a total of 41 alleles), only PGI-2 was monomorphic for the same allele in all the populations studied. Significant deviations from Hardy-Weinberg expectation were observed at some loci in a very few populations. Deviations of $F_{\text {is }}$ from 0 , at the 5 per cent significance level, were observed at $P G I-1$ in populations $4,7,14,38,46$, 56 and 57 (positive deviation) and in population 37 (negative deviation); at $A D H-1$ in populations 8,46 and 54 (positive deviation) and in population 15 (negative deviation). Deviations at the 1 per cent significance level were observed at $I D H-1$ in population 46 (positive deviation) and in no. 49 (negative deviation), and at $P X-1$ in populations 36 and 55 (positive deviation) and in population 32 (negative deviation). Significant positive deviations were also observed $(0.1$ per cent level $)$ at $T O-1$ in population 57 , at $L A P-1$ in populations 32 and 38, and at $A c P H-1$ in population 29. Although most of the $F_{\text {is }}$ deviations from 0 indicate an excess of homozygotes, no particular factor responsible for heterozygote deficiency could be identified. The $G$-test for heterogeneity of allele frequencies was highly significant $(P<0.01$ or lower values) for 19 alleles, namely PGI-1 $1^{1.20}$, PGI-1 $1^{1.09}$, PGI-1 ${ }^{1.00}$, PGI-1 ${ }^{0.80}$, PGI-1 $1^{0.74}$, $A D H-1^{1.00}, A D H-1^{0.76}, P X-1^{1.00}, P X-1^{0.93}, I D H-1^{1.00}$,

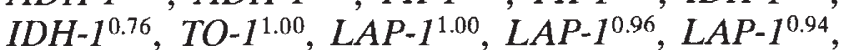
$A C P H-1^{1.05}, A c P H-1^{1.00}, A c P H-1^{0.95}$ and $A c P H-1^{0.83}$, and was significant $(P<0.05)$ for two additional loci, $A D H-1^{0.55}$ and $T O-1^{0.92}$. Heterogeneity could not be tested for the other alleles studied because these were observed at low frequency (less than 10 per cent) and in a very few populations. For the 57 populations scored at six loci, the mean proportion of polymorphic loci was 65 per cent, with values ranging from 33 per cent (in populations 35 and 47) to 83 per cent (in 16 populations). For the 22 populations analysed at eight loci, the mean proportion of polymorphic loci was 73 per cent with a range from 50 per cent (population 28) to 87 per cent (in five populations).

Table 3 shows the percentage of polymorphic loci, mean number of alleles per population, observed heterozygosity, several genetic diversity parameters, mean number of migrants between populations per generation and $F_{\text {is }}$ values calculated either at each of the six loci analysed in $\mathbf{5 7}$ populations of holm oak, or at the two additional loci analysed in 22 populations. Averages over either the six or the eight loci studied were also calculated and indicate high genetic diversity, particularly at the PGI-1 locus with its 11 alleles (see Fig. 4 for their geographical distribution). High genetic diversity was also observed at the $I D H-1, P X-1, L A P-1$ and $A C P H-1$ loci. Mean genetic diversity $\left(H_{\mathrm{s}}=0.126\right)$ at the five polymorphic loci $P G I-1, A D H-1, I D H-1$, $P X-1$ and $T O-1$ was significantly lower $(P<0.0001)$ in the six marginal populations located in areas where climatic conditions constitute a limiting factor for the species than in the whole set of populations. Such low diversity is mainly because of the occurrence of a lower rate of polymorphism in those six marginal populations (mean allele number $(A)=1.87$ over six loci) compared with the nonmarginal populations $(A=2.50)$. Conversely, the five other marginal populations growing under normal climatic conditions, but which were isolated by cultivation areas, showed a high mean genetic diversity value at the same loci $\left(\mathrm{H}_{s}=0.271\right)$ that was not significantly different from the averaged value over the whole set of populations.

Of the average total diversity observed in the holm oak, 10 per cent was attributable to differentiation 
Table 3 Percentage of monomorphic populations $(M)$, total number of alleles per locus $\left(A_{\mathrm{t}}\right)$, mean $(A)$ (minimum-maximum) number of alleles per population, mean effective number of alleles per population $\left(A_{\mathrm{c}}\right)$, observed heterozygosity $\left(H_{\mathrm{o}}\right)$, genetic diversity within populations $\left(H_{\mathrm{s}}\right)$, total genetic diversity $\left(H_{\mathrm{t}}\right)$, proportion (per cent) of diversity among populations $\left(G_{\mathrm{st}}\right)$, mean number of migrants between populations per generation $(\mathrm{Nm})$ and $F_{\text {is }}$ values at five polymorphic loci $P G I-1, A D H-1, I D H-1$, $P X-I$ and $T O-I$ in 57 populations and at loci $L A P-I$ and $A C P H-I$ in 22 populations of holm oak

\begin{tabular}{lrrcccccrrr}
\hline Locus & $M(\%)$ & \multicolumn{1}{c}{$A_{\mathrm{t}}$} & $A$ & $A_{\mathrm{e}}$ & $H_{\mathrm{o}}$ & $H_{\mathrm{s}}$ & $H_{\mathrm{t}}$ & $G_{\text {st }}(\%)$ & $N m$ & $F_{\text {is }}$ \\
\hline$P G I-1$ & 0.0 & 11 & $4.28(2-6)$ & 1.69 & 0.340 & 0.381 & 0.408 & 6.5 & 3.60 & 0.091 \\
$A D H-1$ & 36.5 & 6 & $1.89(1-5)$ & 1.11 & 0.072 & 0.084 & 0.095 & 11.9 & 1.85 & 0.093 \\
$I D H-1$ & 11.3 & 4 & $2.10(1-3)$ & 1.45 & 0.275 & 0.275 & 0.332 & 17.1 & 1.21 & -0.020 \\
$P X-1$ & 0.0 & 7 & $2.99(2-4)$ & 1.58 & 0.328 & 0.335 & 0.369 & 9.3 & 2.45 & -0.003 \\
$T O-1$ & 55.6 & 5 & $1.39(1-3)$ & 1.04 & 0.035 & 0.034 & 0.037 & 6.0 & 3.91 & 0.010 \\
$P G I-2$ & 100.0 & 1 & & & & & & & & \\
Mean & 17.2 & 5.7 & 2.27 & 1.31 & 0.210 & 0.222 & 0.248 & 10.2 & 2.21 & 0.031 \\
LAP-1 & 9.1 & 3 & $2.50(1-3)$ & 1.68 & 0.313 & 0.355 & 0.397 & 10.6 & 2.11 & 0.105 \\
ACPH-1 & 4.5 & 4 & $2.68(1-4)$ & 1.44 & 0.311 & 0.287 & 0.308 & 6.9 & 3.37 & 0.058 \\
Mean & 14.6 & 5.2 & 2.31 & 1.34 & 0.224 & 0.235 & 0.262 & 10.0 & 2.25 & 0.045 \\
\hline
\end{tabular}

Mean values were calculated over the six loci (including the monomorphic PGI-2) analysed in 57 populations, and over the eight loci analysed in 22 populations.

among populations (Table 3$)\left(G_{\text {st }}=10.2\right.$ per cent and 10.0 per cent according to the number of loci and populations analysed). The same conclusion is derived from the $F_{\text {st }}$ average value $(0.10)$ and the mean number of migrants among populations $(\mathrm{Nm}=2.2)$, suggesting that no differention among populations could be ascribed to the unique action of genetic drift (Wright, 1951; Levin \& Kerster, 1974). However, at the IDH-I locus, which showed high total genetic diversity, the $G_{\text {st }}$ value was particularly high compared with values obtained for the other loci studied. Looking at the geographical distribution of allele frequencies at that locus (Fig. 5), evidence was found that most of the differentiation among populations is because of the occurrence of higher $I D H-1^{0.76}$ frequencies in all the populations from the French Atlantic coast than in populations from the other distribution areas. In addition, total genetic diversity was 0.210 and 0.232 in groups of populations showing the 'ilex' and 'rotundifolia' morphotypes, respectively, and the $G_{\text {st }}$ values within these groups ( 9.4 per cent and 9.3 per cent, respectively) were close to that found for the species as a whole.

The low rate of genetic differentiation among populations of holm oak was also obtained from genetic distance computation. Average genetic distance value among the 57 populations scored at six loci was 0.031 (range from 0.002-0.180) for Nei's distance, 0.147 (range from 0.036-0.347) for Gregorius's distance, and 0.047 (range 0.009-0.113) for the $\chi^{2}$ distance. UPGMA coupled with $\chi^{2}$ distance had the high- est cophenetic correlation with the data. The diagram (Fig. 6) shows the respective positions of the 57 populations estimated by the $\chi^{2}$ distance between them. Three sets of populations could be distinguished at the 47 per cent level of agglomeration (a critical value in the agglomeration process) in the UPGMA analysis. Eight of the 10 populations from the French Atlantic coast clustered closely together (set 1 ), as did six of the 10 populations from North Africa (set 3). In contrast, set 2 consisted mainly of populations from the Mediterranean part of the European continent and the three populations from Corsica. Among the 14 populations not clustered at the 47 per cent level, three are marginal populations (no. 9 from Italy, no. 39 from Galicia and no. 54 from Morocco) and two (nos 6 and 7) were collected in Sicily. These latter two populations differed from each other by the occurrence of several distinct alleles. In addition, most of the populations showing the 'rotundifolia' morphotype were located on the right side of the plan parted by axis 2 in Fig. 6 , whereas most of the 'ilex' morphotyped populations were located on the other side. However, no consistent agreement was obtained between the genetic pattern based on allozyme variation and the morphological differentiation pattern as populations showing the 'ilex' and 'rotundifolia' morphotypes as well as those of the intermediate type clustered together in set 2 .

Rare alleles may also contribute significantly to the whole genetic variation in the holm oak. Twelve of the 16 alleles observed in a limited number of populations were specific to a single disjunct region (Table 4). 

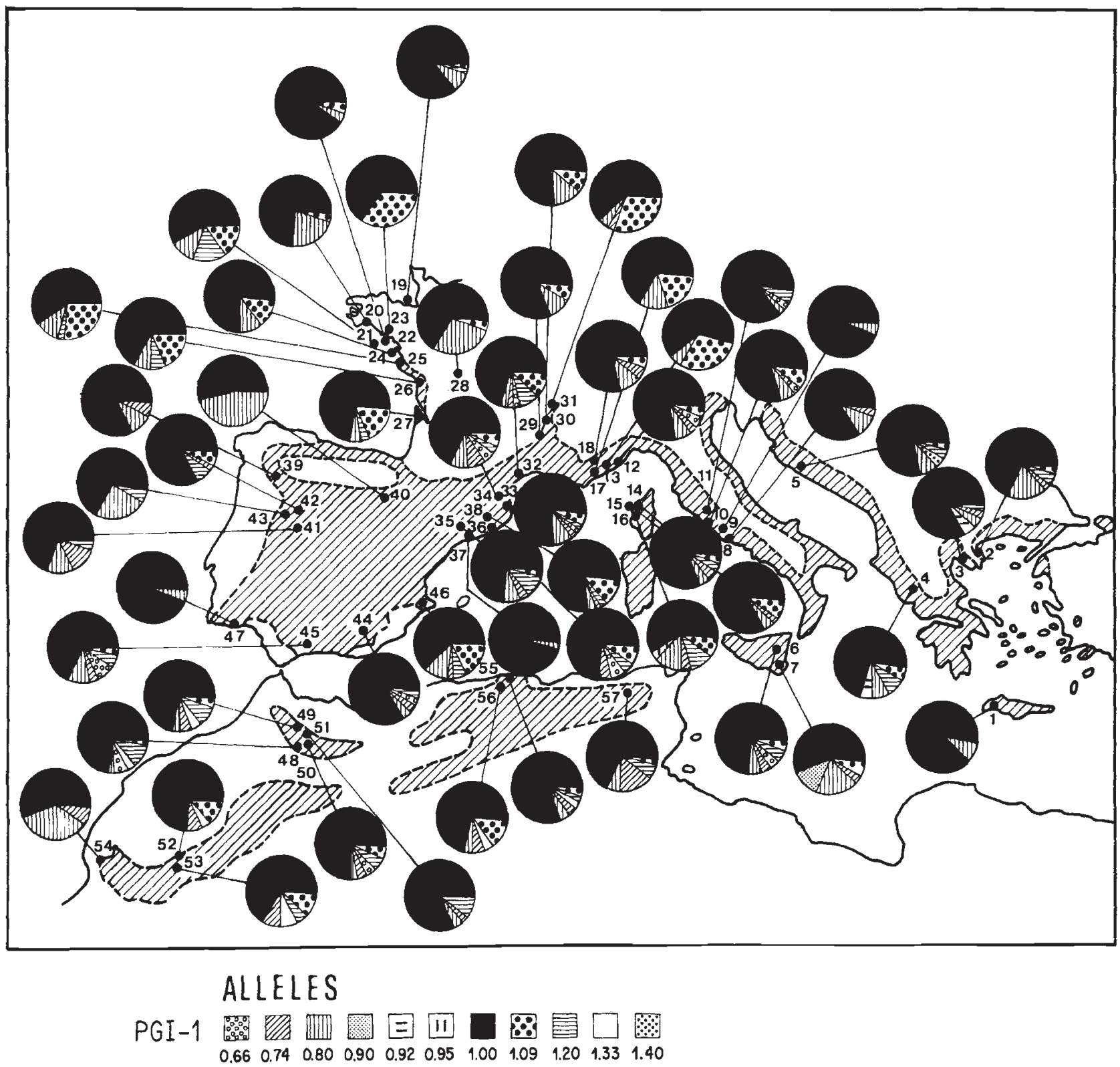

Fig. 4 Geographical distribution of allele frequencies at locus $P G I-1$ in 57 populations of holm oak. On the map, overall species distribution areas are indicated by hatched areas.

The 16 alleles occurred at frequencies lower than 15 per cent. Of the eight alleles present in a single population, three were observed in islands (Sicily and Corsica) and one was found in a marginal population from Galicia. Five alleles present in several populations showed a local distribution: $P G I-I^{1.33}$ in six of the ten studied populations from North Africa (Fig. 4), PGI$1^{0.92}$ in two of the three studied populations from continental Greece (Fig. 4), $A D H-1^{0.55}$ in seven populations located in the eastern part of the holm oak distribution area, $A D H-1^{1.36}$ in three populations from Sicily and central Western Italy and $P X-1^{0.96}$ in two populations from north-western Spain. The three remaining alleles were rare but not restricted to a particular area.

\section{Geographical discontinuity and genetic differentiation among populations}

When the 57 holm oak populations were separated into five groups corresponding to the disjunct regions, total genetic diversity averaged over the groups $\left(H_{\mathrm{gt}}\right)$ was equal to $0.404,0.094,0.364$ and 0.036 at loci PGI-1, ADH-1, PX-1 and TO-1, respectively, and remained therefore very close to the corresponding $H_{\mathrm{t}}$ 
value obtained for the whole 57 populations (Table 3 ). In contrast, at the $I D H-1$ locus, total genetic diversity decreased from 0.332 when calculated over the populations taken as a whole, to 0.287 when the data were averaged over the groups. The among-group diversity $\left(G_{\mathrm{gt}}\right)$ values were very low at the four loci listed above (ranging from 0.3 per cent at TO-1 to 1.5 per cent at $A D H-1$ ) whereas at $I D H-1$, differentiation among the five geographical groups corresponded to 13.5 per cent of the total diversity at that locus. When averaged over the five loci, only 35 per cent of the $G_{\text {st }}$ value calculated over the whole populations $(10.2)$ was attributable to differentiation among groups. The lowest genetic diversity $(0.20$; calculated over the five polymorphic loci and averaged over the populations in each group) was observed in Mediterranean continental Europe whereas the two highest values $(0.26$ and 0.28 ) were obtained in the Atlantic and Sicilian groups, respectively.

Average genetic distances within and between the five disjunct regions were also calculated. With Nei's distance, which is more sensitive to substantial allele frequency variation than are the Gregorius and $\chi^{2}$ distances, values within the disjunct regions ranged from 0.7 per cent for pairs of populations from Corsica to 2.1 per cent for the populations from the French Atlantic coast. Genetic distance between regions ranged from 1.3 per cent between populations from Sicily and those of Mediterranean continental Europe to 8.8 per cent between populations from North Africa
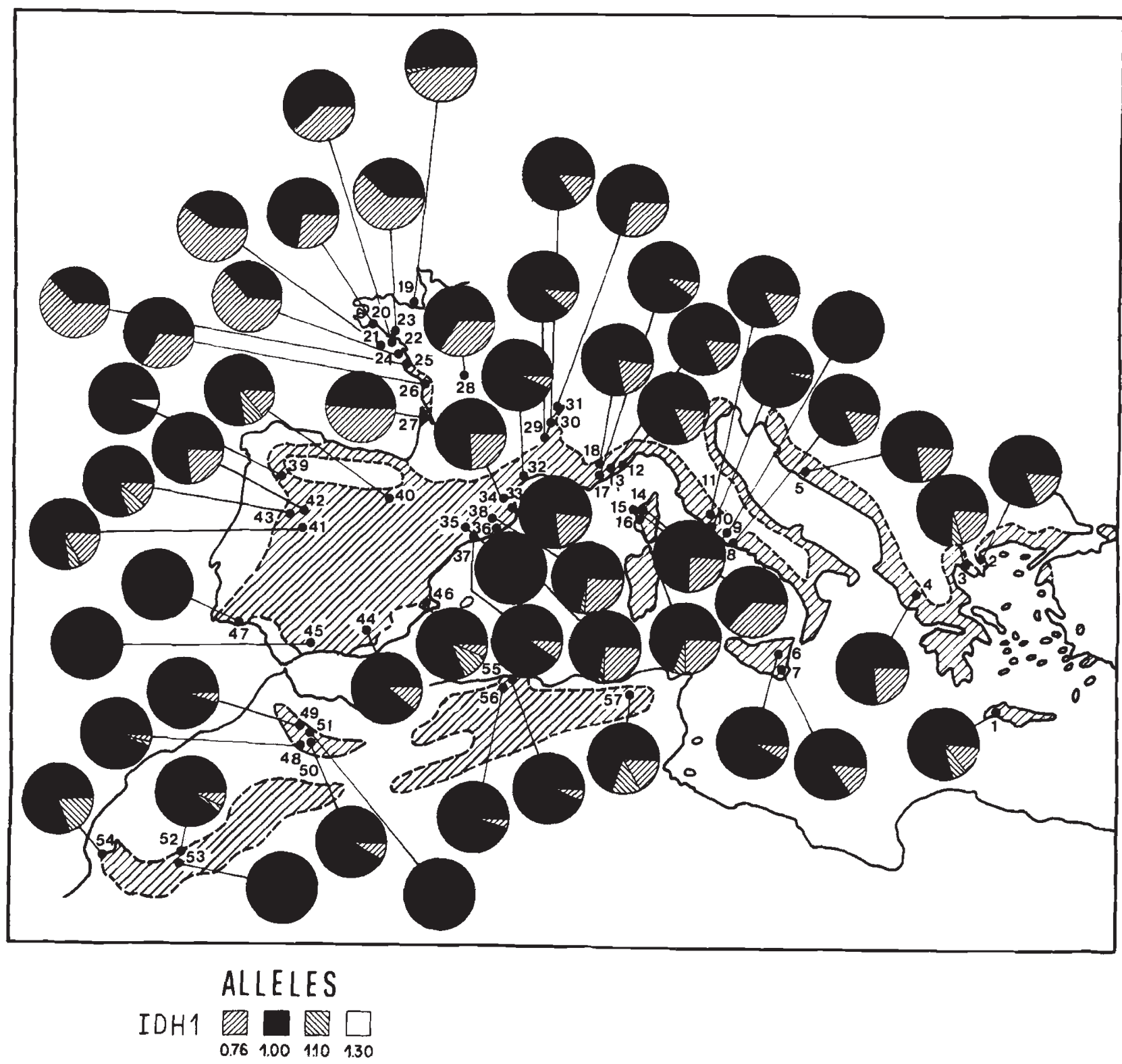

Fig. 5 Geographical distribution of allele frequencies at locus $I D H-1$ in 57 populations of holm oak. 
and those of the Atlantic coast. Using the $\chi^{2}$ distance, which maximizes the effect of rare alleles, the lowest and the highest within-region values were observed for the Corsican and the Sicilian groups, respectively, whereas the lowest and highest between-group values
(1.8 and 8.2 per cent) were found between Corsica and Africa, and between Africa and Sicily, respectively.

In addition, spatial correlograms were obtained from autocorrelation analysis on the 21 alleles that showed significant heterogeneous spatial distribution

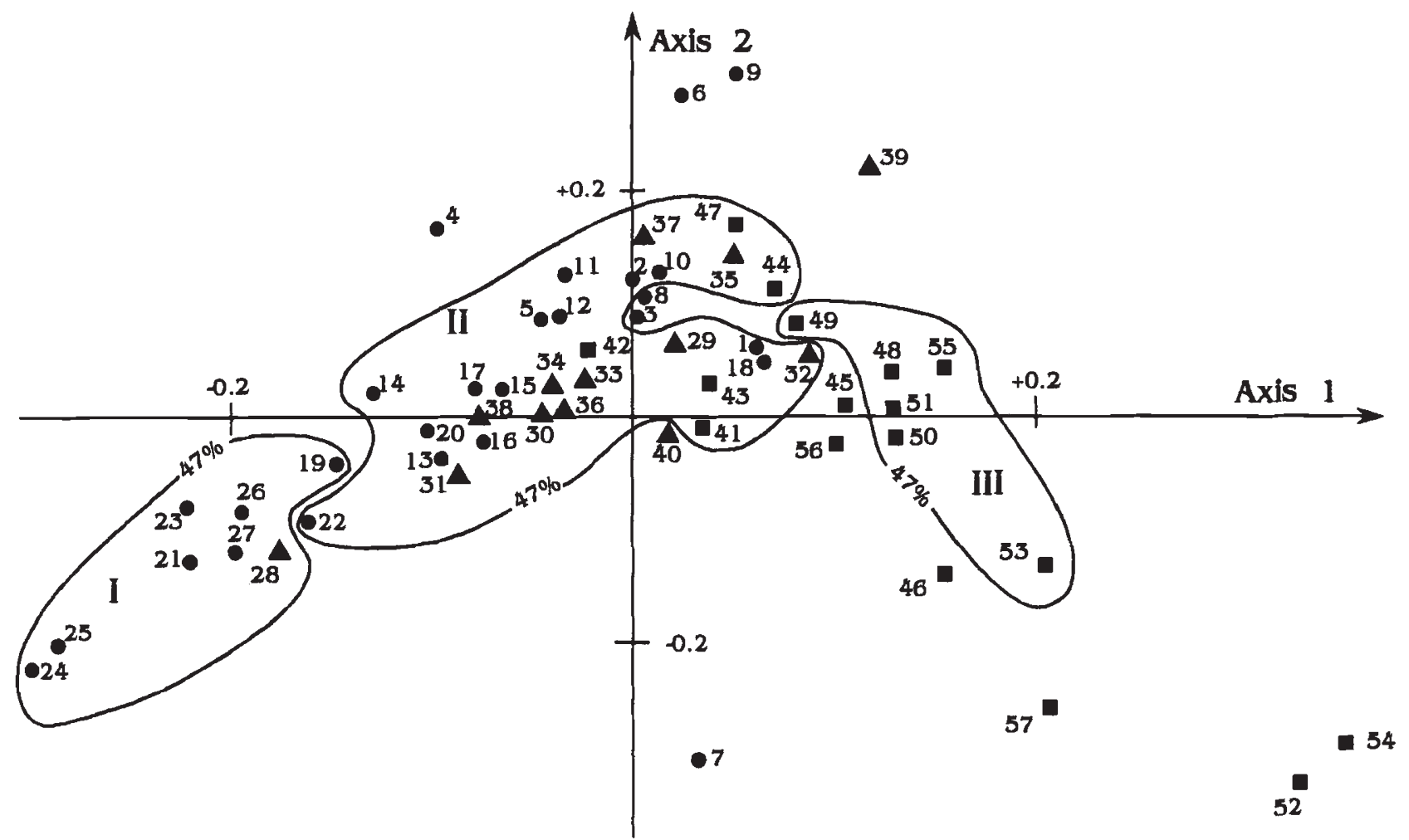

Fig. 6 Position of 57 populations of holm oak showing 'ilex' $(\bullet)$, 'rotundifolia' $(\bullet)$ and 'intermediate' $(\Delta)$ morphotypes, according to polymorphism at loci $P G I-1, I D H-1, A D H-1, P X-1$ and TO-1. Multidimensional scaling from $\chi^{2}$ distances. Populations are clustered at the 47 per cent level of the hierarchical clustering.

Table 4 Identity and location of 16 rare alleles observed at five loci in 57 populations of holm oak

\begin{tabular}{lllll}
\hline Locus & Alleles & \multicolumn{1}{c}{ Populations } & \multicolumn{1}{c}{ Countries } \\
\hline PGI-1 & 0.90 & 7 & Sicily \\
& 0.92 & 3,4 & Greece \\
& 0.95 & 16 & Corsica \\
& 1.33 & $48,49,52,53,55,56$ & Morocco, Algeria \\
& 1.40 & 5 & Croatia \\
ADH-1 & 0.55 & $1,2,3,4,6,7,9$ & Crete, Greece, Italy, Sicily \\
& 1.25 & 18,38 & France, Spain \\
& 1.36 & $7,8,10$ & Sicily, Italy \\
$I D H-1$ & 1.30 & 39 & Spain \\
$P X-1$ & 0.85 & 4 & Greece \\
& 0.96 & 40,41 & Spain \\
& 1.03 & 7 & Sicily \\
TO-1 & 1.08 & 56 & Algeria \\
& 0.86 & $6,12,32$ & Sicily, Italy, France \\
& 0.94 & 48 & Morocco \\
& 1.11 & $33,44,52,55,57$ & France, Spain, Morocco, Algeria, Tunisia \\
& & &
\end{tabular}


(see above). Figure 7 plots the six significant correlograms obtained for $I D H-1^{100}, I D H-1^{0.76}, A D H-1^{0.76}$, $A D H-1^{0.55}, T O-1^{1.00}$ and $T O-1^{0.92}$ from the 57 populations located in the whole distribution area (set 1) and the six correlograms obtained for the same alleles from the 31 populations of the Mediterranean continental group (set 2). Six and five distance classes $(400 \mathrm{~km})$ were used for sets 1 and 2 , respectively. Only two correlograms (for TO- $1^{1.00}$ and TO- $1^{0.92}$ ) were significant for the Mediterranean populations, suggesting that the variation observed in set 1 for the four other alleles $\left(I D H-1^{1.00}, I D H-1^{0.76}, A D H-1^{0.76}\right.$ and $\left.A D H-1^{0.55}\right)$ may result from differentiation among the disjunct regions. As the significance level of each correlogram is 0.05 , a single correlogram out of 20 is expected to be significant by chance. Consequently, the results of autocorrelation analysis obtained in the present study are

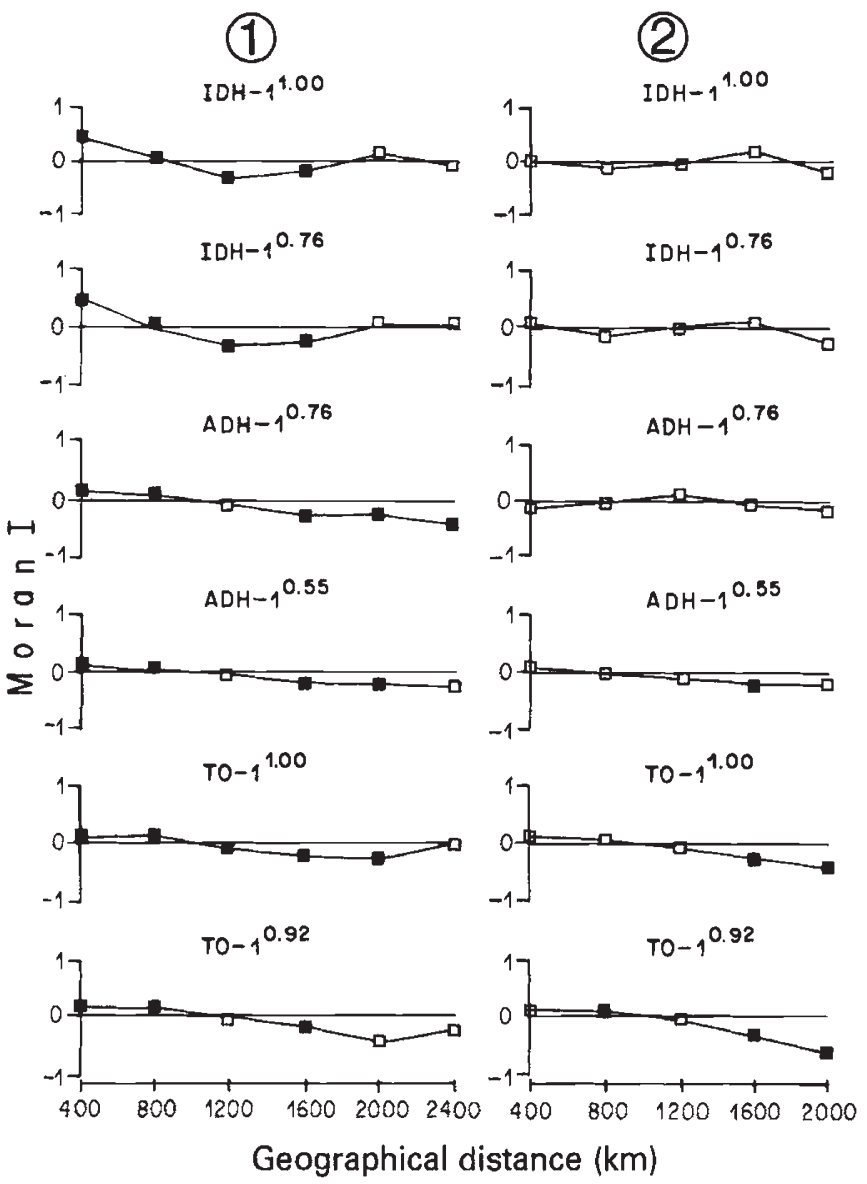

Fig. 7 Spatial autocorrelograms obtained in holm oak for six informative alleles in 57 populations from the whole distribution area (set 1) and in 31 populations from the Mediterranean continental area (set 2). The correlograms are significant except those obtained in set 2 for $I D H-1^{1.00}, I D H$ $1^{0.76}, A D H-1^{0.76}$ and $A D H-1^{0.55}$. Significant $(P \leqslant 0.05)$ and nonsignificant Moran indices are indicated by black and white squares, respectively. robust enough to be considered. Two different kinds of correlograms could be distinguished in set 1: (i) $A D H$ $1^{0.76}, A D H-1^{0.55}$ and, to lesser extent, $T O-1^{1.00}$ and $T O$ $1^{0.92}$ showed a typical clinal pattern with neighbouring populations tending to be characterized by similar frequencies. Similarity decreased with increasing geographical distance, up to the most distant populations which showed negatively correlated frequencies; (ii) a depression model seemed to apply for $I D H-1^{1.00}$ and $I D H-1^{0.76}$ (Sokal \& Oden, 1978a), i.e. whereas the nearest populations (less than $800 \mathrm{~km}$ apart) had positively correlated frequencies, those in the third and fourth classes (between 800 and $1600 \mathrm{~km}$ ) had negatively correlated frequencies. The autocorrelation values approached zero for the two largest geographical distances. The depression pattern may indicate a patchy distribution for the two alleles. As many distance values ranging between 800 and $1600 \mathrm{~km}$ involved one population located in the French Atlantic area and the other in another disjunct region, the depression pattern observed for alleles $I D H-1^{1.00}$ and $I D H-1^{0.76}$ may reflect the occurrence of frequency variation regarding these alleles between the Atlantic and the various other parts of the holm oak distribution area.

\section{Discussion}

\section{Genetic diversity in the whole species distribution}

Total and within-population genetic diversity. The average $F_{\text {is }}$ value per locus (close to zero except at $L A P-1)$ and the total $F_{\text {is }}$ value $(0.04)$ observed in the holm oak suggest a high outcrossing rate for that species. This observation is in agreement with results obtained previously in the holm oak from both direct experimental tests of self-pollination and crosses between half-sibs (Lumaret et al., 1991), and indirect estimates of outcrossing rates using allozyme markers (Yacine \& Lumaret, 1988).

A relatively high genetic diversity estimated by the parameters mentioned above was observed regularly in the holm oak. In this widespread species, the mean number of alleles per locus and the total gene diversity were similar to average values obtained in the other widespread species studied in the Fagaceae, e.g. in Castanea sativa L. (Villani et al., 1991a,b), in Fagus sylvatica L. (Müller-Starck, 1991 and references therein) and in 33 oak species $\left(A=2.41 ; H_{\mathrm{s}}=0.211\right)$ (see Kremer \& Petit, 1993 for a review). However, substantially lower genetic diversity was observed in Nothofagus truncata which has a restricted geographical and ecological distribution range (Haase, 1992), supporting the finding of Hamrick et al. (1992) that, in woody plant species, the level of genetic diversity 
increases significantly with extension of geographical range. In addition, in the holm oak, studies of flowering phenology, breeding system and genetic diversity in progeny of several open-pollinated mother trees have shown that all the sexual reproductive characteristics of this species contribute to maintaining genetic diversity and can efficiently counteract genetic structuring within populations (Yacine \& Lumaret, 1988; Michaud et al., 1992).

Genetic differentiation among populations. In coniferous and in broad-leaved tree species, low genetic differentiation has been observed among populations compared with herbaceous species. Low differentiation in forest trees was attributed mainly to their long life span which favours extensive gene flow (Hamrick et al., 1992). In the holm oak, ten per cent of the total diversity was attributable to differentiation among populations. That value is higher than the mean value ( 7 per cent) obtained over 25 species of oaks studied for enzyme polymorphism (Kremer \& Petit, 1993) and than the genetic differentiation (5 per cent) observed among populations in Fagus sylvatica (Müller-Starck, 1991) and Nothofagus truncata (Haase, 1992). Moreover, in the holm oak, the location of distinct local alleles in three parts of the same continuous distribution area, i.e. in Greece, in both Italy and south-eastern France, and in both Spain and France, can be related to the refuge role played by the three north-south oriented Iberian, Italian and Balkan peninsulas, respectively, during the past glaciations (Bennett et al., 1991; Tzedakis, 1993). In Italian populations of Picea abies such localized alleles were also found in relation to the past role of refugium played by central Italy (Giannini et al., 1991). In the holm oak, clear genetic differentiation among populations growing in areas colonized from distinct putative refuge areas was also observed for chloroplast DNA variation $(\mathrm{H}$. Michaud \& R. Lumaret, unpublished data). Subsequent contacts between populations from distinct refuge areas may have occurred only in the northern distribution area which is restricted by climatic constraints to a narrow strip. Such a situation, which does not favour genetic introgression between the distinct groups of populations, may be responsible for the maintenance of genetic differentiation over long periods.

In the present work, the genetic distance of $\mathrm{Nei}$ averaged over all populations studied is either similar to or even higher than that obtained in other widespread outcrossing species in the Fagaceae, e.g. Castanea sativa in western Europe (Villani et al., 1991a), suggesting that partial barriers to gene flow may occur more frequently in the holm oak. However, in the holm oak, allozyme and morphological differen- tiation patterns were not consistent, indicating that morphological traits and enzyme polymorphisms probably have very distinct sensitivities to environmental selective pressures and therefore may have evolved independently. Discrepancy between variation in proteins and morphology is observed commonly in intraspecific studies of plants (see Linhart et al. 1989, for a review). However, in a few cases, e.g. in Turkish populations of Castanea sativa (Villani et al., 1992), consistent variation patterns of differentiation among populations were observed for allozymic, morphometric and physiological traits, suggesting the occurrence of a certain degree of reproductive isolation within species.

\section{Genetic diversity in marginal populations}

In the holm oak, high genetic diversity was observed in all populations studied except in the six marginal ones growing under unfavourable climatic conditions. In these, only the predominant allele was observed at most of the loci, suggesting that higher selective pressure was occurring in such climatic conditions. Selection on adaptive characters may indeed reduce overall genotype diversity and contribute, therefore, to the loss of low frequency neutral alleles. Conversely, the five holm oak marginal populations growing in cultivated areas under normal climatic conditions for this species showed a high level of genetic diversity which, in such a long-lived species (Yacine \& Lumaret, 1988), may reflect the previous genetic structure established before deforestation of those areas.

\section{Genetic differentiation among the disjunct distribution areas}

As shown in particular by the geographical distribution patterns and the spatial correlograms obtained for several alleles and by the comparison of genetic distances within and between the five disjunct regions of the distribution area, interpopulation genetic differentiation in the holm oak is partly the result of geographical discontinuity in its distribution range. Such discontinuity is responsible for the occurrence of both rare alleles specific for each disjunct area and regional variation for allele frequencies.

Seventy-five per cent of rare alleles were restricted to a single isolated region. For instance, the populations from Morocco and Algeria possess several alleles in common which are specific to North Africa. This result suggests the occurrence of efficient barriers to gene flow among the disjunct regions. Surprisingly, substantial genetic differentiation among populations closely located in the same region was also observed on a few occasions. For instance, the two populations from the 
Etna region in Sicily differed by several rare alleles. Such a situation may be explained by the well-known characteristics of that volcano which releases frequent and successive flows of lava. The holm oak populations growing on Etna have to cope with frequent destruction and recolonization episodes and constitute a patchy distribution of relatively small, isolated subpopulations (Poli \& Maugeri, 1974). These may be subjected to genetic drift.

In the holm oak, the occurrence of regional allele frequencies concerns mainly two alleles, $I D H-1^{0.76}$ and $I D H-1^{1.00}$, the former being predominant in the Atlantic populations whereas the latter is predominant in all the other populations. Holm oak populations from the Atlantic part of France were considered by Pons \& Vernet (1971) as a pre-Würmian relict. Predominance of $I D H-1^{0.76}$ in the French Atlantic populations of holm oak, including those from central and northern Brittany which were introduced a few centuries ago at most, may result from recolonization of those areas from trees growing in a specific relictual region. This should be distinct from the regions from which the Mediterranean populations originate. Alternatively, because it concerns allele frequencies at a single locus, genetic differentiation in the French Atlantic populations may reflect environmental selection (on that locus or on loci tightly linked to it) in areas not subjected to a Mediterranean climate, in contrast to the other disjunct regions of the holm oak distribution. Consistent directional variation in allele frequencies was also recorded by Daubree \& Kremer (1993) in populations of Quercus rubra L. following introduction into Europe, compared with the native American populations. The authors suggested that the variation observed was related to the different natural selection pressures occurring in the two continents.

According to Pons \& Vernet (1971), isolation of the Atlantic populations occurred during the pre-Würmian period (i.e. about 700000 years ago) and is therefore less ancient than the isolation of the several population groups by the Mediterranean sea which occurred approximately five million years ago (Bocquet et al., 1978). However, genetic differentiation of the Atlantic populations is higher than that present among the Mediterranean groups which is limited to the occurrence of localized alleles which are always observed at low frequency.

The main conclusion to emerge from this study is that life history traits (especially long life span and outcrossing) and the evolutionary history of the holm oak related to changes in both climate and geographical continuity probably played a major role among the manifold factors responsible for the present genetic variation pattern observed in this species.

\section{Acknowledgements}

We are grateful to Dr Stratis Kiriakakis from the Forest Directory of Chania Prefecture (Crete), Dr Basile Noïtsakis from University of Salonique (Greece), Dr Solitis Kandrelis from Ionina Institute (Greece), Dr Hubert Etienne from INRA Forestry Institute of Avignon (France), Dr Bacic Tomislav from Split University (Croatia), Professor Salvatore Leonardi from University of Catania (Sicily), Marie Maistre and Philippe Perret from CEFE-CNRS, Montpellier (France), Marc-André Selosse from Belle-île (France), Damien de Bouêt du Portal from La Rochelle (France), Dr Noureddine Ouazzani from Ecole Nationale Agronomique of Méknès (Morocco), Dr Assia Yacine, Ecole Agronomique d'Alger (Algeria) and Mokthar Smaali, Institute of Forestry, Ain-Draham (Tunisia) for collecting holm oak leaf material. We thank Dr James Aronson for his helpful comments and advice on the manuscript, Dr Guillon (Bioclimatology group, INRA La Ferrade) for geographical co-ordinates transformation and Dr Rémi Petit (Dr Kremer's group, INRA, Pierroton, France) for supplying us with their program to calculate Moran's autocorrelation index.

\section{References}

AFZAL-RAFI, z. 1988. Caractéristiques taxonomiques, morphologiques et isoenzymatiques du complexe 'chêne vert'. Bull. Soc. bot. Fr., 135, 343-352.

AFZAL-RAFIl, Z., ZAVARIN, E. AND PELlEAU, y. 1991a. Chemosystematic differentiation of Quercus ilex and Quercus rotundifolia based on acorn fatty acids. Biochem. Syst. Ecol., 19, 163-166.

AFZAL-RAFII, Z., ZAVARIN, E. AND PELleAU, Y. 1991b. Chemosystematic differentiation of Quercus ilex and Quercus rotundifolia based on acorn steroids. Biochem. Syst. Ecol., 19, 249-252.

AFZAL-RAFI, Z., DODD, R. S. AND PELLEAU, Y. 1992. Mediterranean evergreen oak diversity: morphological and chemical variation of acorns. Can. J. Bot., 70, 1459-1466.

BARBERO, M., LOISEL, R. AND QUEZEL, P. 1992. Biogeography, ecology and history of Mediterranean Quercus ilex $\mathbf{L}$. ecosystems. Vegetatio, 99-100, 19-34.

BENNETT, K. D., TZEDAKIS, P. C. AND WILLIS K. J. 1991. Quaternary refugia of north European trees. J. Biogeogr., 18, 103-115.

BETANCOURT, J. L., SCHUSTER, W. S., MITTON, J. B. AND SCOTT ANDERSON, R. 1991. Fossil and genetic history of a pinyon pine (Pinus edulis) isolate. Ecology, 72, 1685-1697.

BOCOUET, G.,WIDLER, B. AND KIEFER, H. 1978. The Messinian model: a new outlook for the floristics and systematics of the Mediterranean area. Candolea, 33, 269-287.

CHUNG, M. S. 1991. Observations on the genetic structure of Pinus densiflora Sieb et Zucc (I): the Young-il population. J. Korean Forest. Soc., 80, 246-254. 
DAUBREE, J. B. AND KREMER, A. 1993. Genetic and phenological differentiation between introduced and natural populations of Quercus rubra L. Ann. Sci. For., 50, 271s-280s.

DUCOUSSO, A., MICHAUD, H. AND LUMARET, R. 1993. Reproduction and gene flow in the genus Quercus. Ann. Sci. For., 50, $91 \mathrm{~s}-106 \mathrm{~s}$.

DUPONT, P. 1990. Atlas partiel de la flore de France. Museum National d'histoire Naturelle, Paris.

EMBERGER, L. 1955. Une classification biogéographique des climats. Naturalia Monspeliensa, 7, 3-43.

ESCOUFIER, Y. 1975. Le positionnement multidimentionnel. Rev. Stat. Appl., 4, 5-14.

FINESCHI, S. 1984. Determination of the origin of an isolated group of trees of Pinus nigra through enzyme gene markers. Silvae Genet., 33, 169-172.

FONT TUllot, J. 1983. Climatologia de España y Portugal. Instituto Nacional de Meteorología, Madrid.

FURNIER, G. R. AND ADAMS, w. T. 1986. Geographic patterns of allozyme variation in Jeffrey pine. Am. J. Bot., 73, 1009-1015.

GARNIER, M. 1964. Valeurs normales des températures en France (1921-1950). Monographie Météoriologie Nationale, No. 30, Paris.

GARNIER, M. 1966. Valeurs normales des hauteurs de précipitations en France I-Période 1931-1960, II-Période 1901-1950. Monographie Météoriologie Nationale, No. 55, Paris.

GASQUeS, J. AND Compoint, J. P. 1976. Apport de l'électrophorèse en courant pulsé à la taxonomie d'Echinochloa crus-galli (L.) P.B. Annls Amél. Pl., 26, 345-355.

GIANNINI, R., MORGANTE, M. AND VENDRAMIN, G. G. 1991. Allozyme variation in Italian populations of Picea abies (L.) Karst. Silvae Genet., 40, 160-166.

GOTTLIEB, L. D. 1977. Electrophoretic evidence and plant systematics. Ann. Mo. Bot. Gard., 64, 161-180.

GovinDARAJU, D. R. 1988. Relationship between dispersal ability and levels of gene flow in plants. Oikos, 59, 31-35.

GREGORIUS, H.-R. 1984. A unique genetic distance. Biom. J., 26, 13-18.

HAASE, P. 1992. Isozyme variability and biogeography of Nothofagus truncata (Fagaceae). N. Z. J. Bot., 30, 315-328.

HAGEMANN, R. AND SCHROEDER, M. B. 1989. The cytological basis of the plastid inheritance in angiosperms. Protoplasma, 152, 57-64.

HAMRICK, J. L., LINHART, Y. B. AND MITTON, J. B. 1979. Relationships between life history characteristics and electrophoretically detectable genetic variation in plants. Ann. Rev. Ecol. Syst., 10, 173-200.

HAMRICK, J. L., BLANTON, H. M. AND HAMRICK, K. J. 1989. Genetic structure of geographically marginal populations of ponderosa pine. Am. J. Bot., 76, 1559-1568.

HAMRICK, J. L., GODT, M. J. W. AND SHERMAN-BROYLES, S. L. 1992. Factors influencing levels of genetic diversity in woody plant species. New Forests, 6, 95-124.

KEPHART, S. R. 1990. Starch gel electrophoresis of plant isozymes: a comparative analysis of techniques. Am. J. Bot., 77, 693-712.

KREMER, A. AND PETIT, R. J. 1993. Gene diversity in natural populations of oak species. Ann. Sci. For., 50, 186s-202s.
KREMER, A., PETIT, R. J., ZANETTO, A., FOUGERE, V., DUCOUSSo, A., WAGNER, D. AND CHAUVIN, C. 1991. Nuclear and organelle gene diversity in Quercus robur and Quercus petraea. In: Müller-Starck G. and Ziehe M. (eds) Genetic Variation in European Populations of Forest Trees, pp. 141-166. J. D. Sauerländer, Frankfurt am Main.

LAMB, H. F., EICHER, V. AND SWITSUR, V. R. 1989. An 18,000-year record of vegetation, lake-level and climate change from Tigalmamine, Middle Atlas, Morocco. J. Biogeogr., 16, 65-74.

LEBRETON, J. D., ROUX, M., BANCO, G. AND BACOU, A. M. 1987. The BIOMECO Package. Centre Emberger, Centre National de la Recherche Scientifique, Montpellier, France.

LE houérou, H. N. 1989. Classification écoclimatique des zones arides (s.l.) de l'Afrique du Nord. Ecol. Medit., 15, 95-144.

LEVIN, D. A. AND KERSTER, H. W. 1974. Gene flow in seed plants. Evol. Biol., 7, 139-220.

LI, C. C. AND HORVITZ, D. G. 1953. Some methods of estimating the inbreeding coefficient. Am. J. Hum Genet., 5, 107-117.

LINHART, Y. B., GRANT, M. C. AND MONTAZEN, P. 1989. Experimental studies in ponderosa pine. I. Relationships between variation in proteins and morphology. Am. J. Bot., 76, 1024-1032.

Lombardo, r. 1973. Contribution à une description du climat de la Corse. Monographie Météorologie Nationale, No. 61, Paris.

LOVELESS, M. D. AND HAMRICK, J. L. 1984. Ecological determinants of genetic structure in plant populations. Ann. Rev. Ecol. Syst., 15, 65-95.

LUMARET, R. 1981. Etude de l'hérédité de phosphatases acides chez le dactyle (Dactylis glomerata L.) diploïde et tetraploïde. Can.J. Genet. Cytol., 23, 513-523.

LUMARET, R., YACINE, A., BERROD, A., ROMANE, F. AND LI, T. X. 1991. Mating system and genetic diversity in holm oak (Quercus ilex L. Fagaceae). In: Fineschi, S., Malvolti, M. E., Cannata, F. and Hattemer, H. H. (eds) Biochemical Markers in the Population Genetics of Forest Trees, pp. 145-153. SPB Academic Publishing, The Hague, The Netherlands.

MAIRE, R. 1961. Flore de l'Afrique du Nord, vol. 7. Lechevallier, Paris.

MAYR, E. 1975. Populations, Species, and Evolution. Harvard University Press, Cambridge, MA.

MICHAUD, H., LUMARET, R. AND ROMANE, F. 1992. Variation in the genetic structure and reproductive biology of holm oak populations. Vegetatio, 99-100, 107-113.

MORAN, P. A. P. 1950 . Notes on continuous stochastic phenomena. Biometrika, 37, 17-23.

MÜLLER-STARCK, G. 1991. Survey of genetic variation as inferred from enzyme gene markers. In: Müller-Starck, G. and Ziehe, M. (eds) Genetic Variation in European Populations of Forest Trees, pp. 20-37. J. D. Sauerländer, Frankfurt am Main.

MÜlLER-STARCK, G., BARADAT, PH AND BERGMANN, F. 1992. Genetic variation within European tree species. New Forests, 6, 23-47.

NEI, M. 1973. Analysis of gene diversity in subdivided populations. Proc. Natl. Acad. Sci. .U.S.A., 70, 3321-3323. 
NEI, M. 1977. F-statistics and analysis of gene diversity in subdivided populations. Ann. Hum. Genet., 41, 225-233.

NEI, M. 1978. Estimation of average heterozygosity and genetic distance from a small number of individuals. Genetics, 89, 583-590.

NEl, M. 1987. Molecular Evolutionary Genetics. Columbia University Press, New York.

ODEN, N. L. 1984. Assessing the significance of a spatial correlogram. Geogr. Analr., 16, 1-16.

OUAZZANI, N., LUMARET, R., VILLEMUR, P. AND DI GIUSTO, F. 1993. Leaf allozyme variation in cultivated and wild olive trees (Olea europea L.). J. Heredity, 84, 34-42.

PALAMAREV, E. 1989. Paleobotanical evidences of the tertiary history and origin of the Mediterranean sclerophyll dendroflora. Pl. Syst. Evol, 162, 93-107.

PETIT, R. J., KREMER, A. AND WAGNER, D. B. 1993. Geographic structure of chloroplast DNA polymorphisms in European oaks. Theor. Appl. Genet., 87, 122-128.

POLI, E. AND MAUGERI, G. 1974. I boschi di leccio del versante nordoccidentale dell'Etna. Boll. Acad. Gioenia Sci. Nat. Catania, 12, 741-759.

PONS, A. AND THINON, M. 1987. The role of fire from paleoecological data. Ecol. Medit., 13, 3-11.

PONS, A. AND VERNET, J. L. 1971. Une synthèse nouvelle de l'histoire du chêne vert (Quercus ilex L.). Bull. Soc. bot. Fr., 118, 841-850.

QUEZEL, P. 1976. Les forêts du pourtour méditerranéen. In: Forêt et maquis méditerranéens: écologie, conservation et aménagement. Tech. notes of M. A.B, 2, pp. 9-33. Unesco.

REILlE, M. 1976. Analyse pollinique de sédiments postglaciaires dans le Moyen Atlas et le Haut Atlas marocains: premiers résultats. Ecol. Medit., 2, 153-170.

REILLE, M. AND PONS, A. 1992. The ecological significance of sclerophyllous oak forests in the western part of the Mediterranean basin: a note on pollen analytical data. Vegetatio, 99-100, 13-17.

ROHLF, F. J. 1987. NTSYS-pc, version 1.30. Applied Biostatistics, New York.

Roux, M. 1985. Algorithmes de Classification. Méthodes et Programmes. Masson, Paris.

RUPEREZ, A. 1957. La encina y sus tratamientos. Editiones selvícolas, Madrid.

SAENZ DE RIVAS, C. 1967. Estudios sobre Quercus ilex L. y Quercus rotundifolia Lamk. Anales Inst. Bot. A.J. Cavanilles, 25, 243-262.

SAENZ DE RIVAS, C. 1970. Biométria foliar de una población de Quercus ilex L., subsp. rotundifolia (Lamk.) T. Morais, en El Pardo. Anales. Inst. Bot. A. J. Cavanilles, 27, 105-114.

SAENZ DE RIVAS, C. 1972. Biométria foliar de una población de Quercus ilex L. en Montserrat (Barcelona). Anales. Inst. Bot. A.J. Cavanilles, 29, 39-57.

schwarTz, o. 1964. Quercus. In: Tutin T. G., Heywood, V. H., Burges, N. A., Valentine, D. H., Walters, S. M. and Webb, D. A. (eds) Flora Europaea, vol. I, pp. 61-64. Cambridge, University Press, London.

SELANDER, R. K. , SMITH, M. H. , YANG, S. Y. , JOHNSON, W. E. AND GENTRY, J. B. 1971. Biochemical polymorphism and systematics in the genus Peromyscus. I Variation of the old-field mouse (Peromyscus polionotus). Studies in genetics VI. University of Texas Publication, 7103, 49-90.

SLATKIN, M. 1987. Gene flow and the geographic structure of natural populations. Science, 236, 787-792.

SOKAL, R. R. AND ODEN, N. L. 1978a. Spatial autocorrelation in biology. 1. Methodology. Biol. J. Linn. Soc, 10, 199-228.

SOKAL, R. R. AND ODEN, N. L. 1978b. Spatial autocorrelation in biology. 2. Some biological implications and four applications of evolutionary and ecological interest. Biol. J. Linn. Soc., 10, 229-249.

SOKAL, R. R. AND RoHLF, F. J. 1981. Biometry, 2nd edn. W. F. Freeman, San Francisco.

SWOFFORD, D. L. AND SELANDER, R. B. 1989. BIOSYS-1. A computer program for the analysis of allelic variation in population genetics and biochemical systematics. Release 1. 7. University of Illinois, Urbana, Illinois.

TZEDAKIS, P. C. 1993. Long-term tree populations in northwest Greece through multiple Quaternary climatic cycles. Nature, 364, 437-440.

VAN TREUREN, R., BIJLSMA, R., VAN DELDEN, W. AND OUBORG, N. J. 1991. The significance of genetic erosion in the process of extinction. I. Genetic differentiation in Salvia pratensis and Scabiosa columbaria in relation to population size. Heredity, 66, 181-189.

VILLANI, F., BENEDETTELli, S., PACIUCCI, M., CHERUBinI, M. AND PIGLIUCCI, M. 1991a. Genetic variation and differentiation between natural populations of chestnut (Castanea sativa Mill.) from Italy. In: Fineschi, S., Malvolti, M. E. , Cannata, F. and Hattemer, H. H. (eds) Biochemical Markers in the Population Genetics of Forest Trees, pp. 91-103. SPB Academic Publishing, The Hague, The Netherlands.

VILLANI, F., PIGLIUCCI, M., BENEDETTELLI, S. AND CHERUBiNI, M. 1991b. Genetic differentiation among Turkish chestnut (Castanea sativa Mill.) populations. Heredity, 66, 131-136.

VILLANI, F., PIGLIUCCI, M., LAUTERI, M., CHERUBINI, M. AND SUN, O. 1992. Congruence between genetic, morphometric and physiological data on differentiation of Turkish chestnut (Castanea sativa). Genome, 35, 251-256.

WALTER, H. AND LIETH, H. 1960-1967. Klimadiagramm Weltatlas. VEb Gustav Fischer, Jena, Germany.

WRIGHT, s. 1951. The genetical structure of populations. Ann. Eugen., 15, 323-354.

WRIGHT, s. 1965. The interpretation of population structure by $F$-statistics with special regard to systems of mating. Evolution, 19, 395-420.

YACINE, A. AND LUMARET, R. 1988. Distribution spatiale des génotypes dans une population de chêne vert (Quercus ilex L.), flux génique et régime de reproduction. Génét. Sél. Évol., 20, 181-198.

YACINE, A. AND LUMARET, R. 1989. Genetic diversity in HolmOak (Quercus ilex L.): insight from several enzyme markers. Silvae Genet., 38, 3-4.

ZABINSKI, C. 1992. Isozyme variation in eastern hemlock. Can. J. For. Res., 22, 1838-1842. 